\title{
A STUDY ON EFFECTS OF ESR GENE POLYMORPHISM ON REPRODUCTIVE TRAITS OF F1 HYBRID WILD BOAR ( BOAR X $q$ VCNMS15) IN FARM HOUSEHOLDS.
}

\author{
${ }^{1}$ Truong Huu Dung; ${ }^{1}$ Phung Duc Hoan; ${ }^{1}$ Tran Van Phung \\ ${ }^{1}$ Thai Nguyen University of Agriculture and Forestry \\ DOI: https://doi.org/10.51193/IJAER.2021.7211
}

\begin{abstract}
Studying on the effect of ESR gene polymorphism on the reproductive traits of F1 hybrid wild boars ( ${ }^{\lambda} \mathrm{R}$ Wild Boars $\mathrm{x}$ + $\mathrm{VCNMS15}$ ) determined the correlation between ESR gene polymorphism with reproductive capacity of sows which were monitored directly more than 20 F1 sows ( $\sigma^{\lambda}$ Wild Boars $\mathrm{x}$ + $\mathrm{VCNMS15}$ ) raised on the households. The data was processed and analyzed on statistical software, the correct sampling method, the process of separation, extraction and analysis of ESR gene polymorphism on modern equipments, the results showed:

Successfully analyzed ESR gene polymorphism from 20 individual $\mathrm{F} 1$ sows (ðWild Boars $\mathrm{x}$ +VCNMS15) identified 3 genotypes AA; AB; BB. The results obtained the difference in genotype, as follows: 8 individuals with genotype AA accounted for 40\%, 11 individuals with genotype $\mathrm{AB}$ accounted for $55.00 \%$ and 1 individual with genotype $\mathrm{BB}$ accounted for $5,00 \%$. The difference in the A and B allele frequencies of the studied samples was clearly shown, the A allele frequency of 0.67 accounts for a higher percentage than the B allele frequency of 0.33 .

Initially the researchers determined the correlation between genotype ESR polymorphism for the reproductive traits of F1 wild boars ( $O^{\lambda}$ Wild Boars $\mathrm{x}$ +VCNMS15). Wild boars carrying genotype $\mathrm{AB}$ in ESR gene showed higher reproductive performance than genotypes $\mathrm{AA}$ and $\mathrm{BB}$ with $(\mathrm{P}<0.05)$.
\end{abstract}

Keywords: Wild boars F1 (ðึWild boars x + VCNMS15); genetic polymorphism; gene ESR; reproductive traits; genotype.

\section{INTRODUCTION}


International Journal of Agriculture and Environmental Research

ISSN: 2455-6939

Volume: 07, Issue: 02 "March-April 2021"

Wild boars and F1 hybrid wild boars were raised in some northern mountainous provinces of our country, with many advantages such as quality of fragrant meat, high lean rate, high nutritional value, no antibiotic residues and the ability to withstand miserable farming conditions. However, there were limitations such as the number of children born per litter, the growth and development slowly. Therefore, in order to exploit and develop this breed of wild boar, it is necessary to have researches and solutions to increase productivity in livestock production.

Nowadays, genetic technology has been widely used in practical production, the development of molecular genetic engineering, many genes associated with reproductive traits have been studied to improve productivity. breeding in sows, bringing high economic efficiency in breeding. In order to enhance pig reproductive traits by breeding selection was difficult due to the low genetic ability of these traits, researchers have selected livestock breeds based on molecular markers in order to increase the primary ability accuracy, shorten time and increase selectivity. In particular, research on the correlation of genetic polymorphism with reproductive traits was very important in the conservation of varieties. According to research by Drogemuller et al. (2001) [6]; Omelka et al. (2008) [9] showed that the estrogen receptor gene (ESR) was related to reproductive performance of the sow. The pig's ESR gene was closely related to pregnancy and its receptor function, which had a characteristic allele associated with the number of offspring born.

With the aim of applying modern techniques of genetic engineering and molecular genetic engineering in pig production to bring the highest economic efficiency to the breeder while retaining the outstanding advantages of the breed, we conducted this study to investigate the correlation between the ESR gene polymorphism with the reproductive traits of F1 hybrid wild boar ( 0 wild boar $\mathrm{x}$ +VCNMS15) raised in the farm households.

\section{RESEARCH MATERIALS AND RESEARCH METHODOLOGY}

\subsection{Research Materials}

The study was conducted on $20 \mathrm{~F} 1$ sows ( 3 wild boar $\mathrm{x}$ +VCNMS15) raised at the Indigenous Plant and Animal Research and Development Branch, Tuc Tranh commune, Phu Luong district, Thai Nguyen province.

Pigs ${ }^{\lambda}$ Vietnam Wild Boar; Pigs $९$ VCNMS15: is the Meishan pig breed imported from China by the National Institute of Livestock of Vietnam and purebred with the name VCNMS15.

Research period: The study was conducted from January 1, 2019 to December 31, 2020

\subsection{Research methodology and some monitoring indicators}




\section{Research content}

ESR gene polymorphism analysis of $\mathrm{F} 1$ sows (ठ̂wild boar $\mathrm{x}$ +VCNMS15): Total DNA extraction from obtained ear tissue samples; PCR cloning specific gene PRLR; Cut reaction with corresponding restriction enzyme.

Determination of genetic polymorphism correlation of ESR genes to reproductive traits of F1 sows ( $§$ Rung x $९$ VCNMS15).

\section{Sampling method}

Using specialized pliers to click a sample of the ear tissue of the experimental pig, then put it into an eppendoft tube containing $70 \%$ alcohol. The sample was stored at $-200 \mathrm{C}$ and then used to separate total DNA.

\section{Methods of DNA extraction}

Total DNA extraction using proteinase $\mathrm{K}$ method.

DNA quality testing, using the NanoDrop 2000 machine to check the purity and concentration of DNA after extraction at $260 \mathrm{~nm}$ and $280 \mathrm{~nm}$.

Principle: The NanoDrop 2000 purity tester worked on the strong absorption of ultraviolet light at 260 wavelengths of purine and pyrimidine bases. Values of the optical density at $260 \mathrm{~nm}$ of these samples allowed the determination of the DNA concentration in the samples based on the following correlations:

One unit OD260 corresponds to a concentration of $50 \mu \mathrm{g} / \mathrm{ml}$ for a double strand DNA solution. In which a unit OD260 corresponded to the concentration of DNA $=50(\mu \mathrm{g} / \mathrm{ml})$.

To test the purity of DNA in solution, measure the OD value at 280 (OD280). The wavelength of 280 was the wavelength at which proteins had the highest absorption, but proteins also absorbed light at 260 just as nucleic acid molecules could thus distort the true concentration value of the nucleic acid.

To ensure the correct concentration of CDNA, we used value A260 / A280. When the value A260 / A280 $=1.8-2.0$, the DNA extract was considered purified (Khuat Huu Thanh, 2012) [2].

\section{PCR method}


Ingredients for a reaction include: Enzyme Taq-polymerase, buffer Taq-polymerase (buffer), corresponding primer, $\mathrm{MgCl} 2$, dNTP, purified water and template DNA. ESR primers were designed by Short et al. 1997.

\section{Limit enzyme cutting method}

After amplification, a 120 bp ESR gene segment was cut with PvuII enzyme by overnight incubation at $370 \mathrm{C}$.

\section{Analysis of genetic polymorphism}

The genotype frequency and allelic forms were summarized of the PRLR gene with the following proportions of the cut-outs: Allel A: 85bp - 59bp - 19bp; Allel B: 104bp - 59bp. And so the corresponding frequencies of the corresponding genes would be: Genotype AA: 85bp 59bp - 19bp; Genotype AB: 104bp - 85bp - 59bp - 19bp; Genotype BB: 104bp - 59bp

Monitoring some sow fertility indicators including indicators of number of offspring / litter; number of children alive after 24 hours; number of children weaned; birth / baby weight; the weight of weaned piglets.

Data were collected, processed and analyzed statistically on Minitab.16 software.

\section{RESULTS AND DISCUSSION}

\subsection{Results of analysis of ESR gene polymorphism (Estrogen Receptor)}

\subsubsection{Results of total DNA extraction from F1 sow ear samples (}

The results of DNA extraction for a total of 8 F1 sow ear samples (ð̋wild boar $\mathrm{x}$ q VCNMS15) are represented as shown in Figure 3.1 


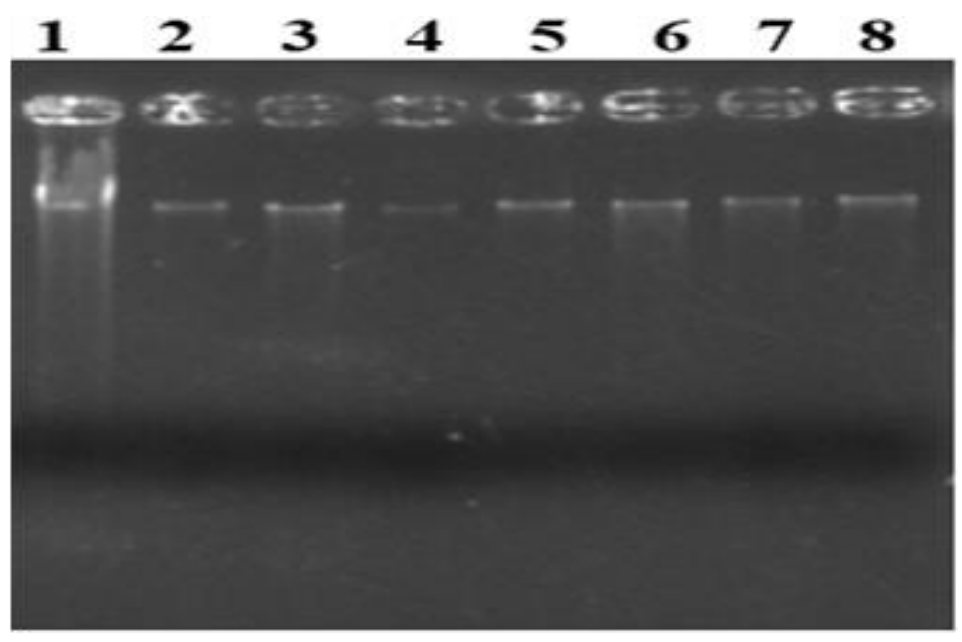

Figure 3.1: Results of DNA extraction for a total of $8 \mathrm{~F} 1$ sow ear tissue samples ( $\circlearrowright$ wild boar $\mathbf{x}$ +VCNMS15)

(Track from 1-8: total ear tissue DNA product of F1 sow samples (ð̋ wild boar x $\bigcirc$ VCNMS15))

From the results of electrophoresis of the above DNA separating products, the total DNA samples obtained had relatively good quality. DNA was less prone to fracture, the bands were brightly. The concentration and purity of the obtained DNA samples were shown in Table 3.1

Table 3.1: Results of DNA purity and concentration measurement

\begin{tabular}{|c|c|c|}
\hline Research sample & $\mathbf{O D}_{\mathbf{2 6 0}} \mathbf{O O D}_{\mathbf{2 8 0}} \mathbf{r a t i o}$ & DNA concentration $(\mathbf{n g} / \boldsymbol{\mu l} \mathbf{)}$ \\
\hline 1 & 1,92 & 35,4 \\
\hline 2 & 1,81 & 40,5 \\
\hline 3 & 1,89 & 36,5 \\
\hline 4 & 1,98 & 35,8 \\
\hline 5 & 1,90 & 36,8 \\
\hline 6 & 1,95 & 38,7 \\
\hline 7 & 1,87 & 39,5 \\
\hline 8 & 1,97 & 38,8 \\
\hline
\end{tabular}


From the above results, it shows that the ratio of OD260 / OD280 in the studied samples was relatively uniform. The results ranged from 1.80 to 1.99 within the permissible limits (1.80 2.00). Therefore, the obtained DNA samples were fully qualified for PCR reaction and further studies.

\subsubsection{PCR results amplify ESR gene with specific primers}

The PCR product of the ESR gene segment was multiplied from primers designed by Short et al. 1997 [10] with an expected size of $120 \mathrm{bp}$. The product was finished after multiplying electrophoresis on $1 \%$ agarose gel in 35 minutes.

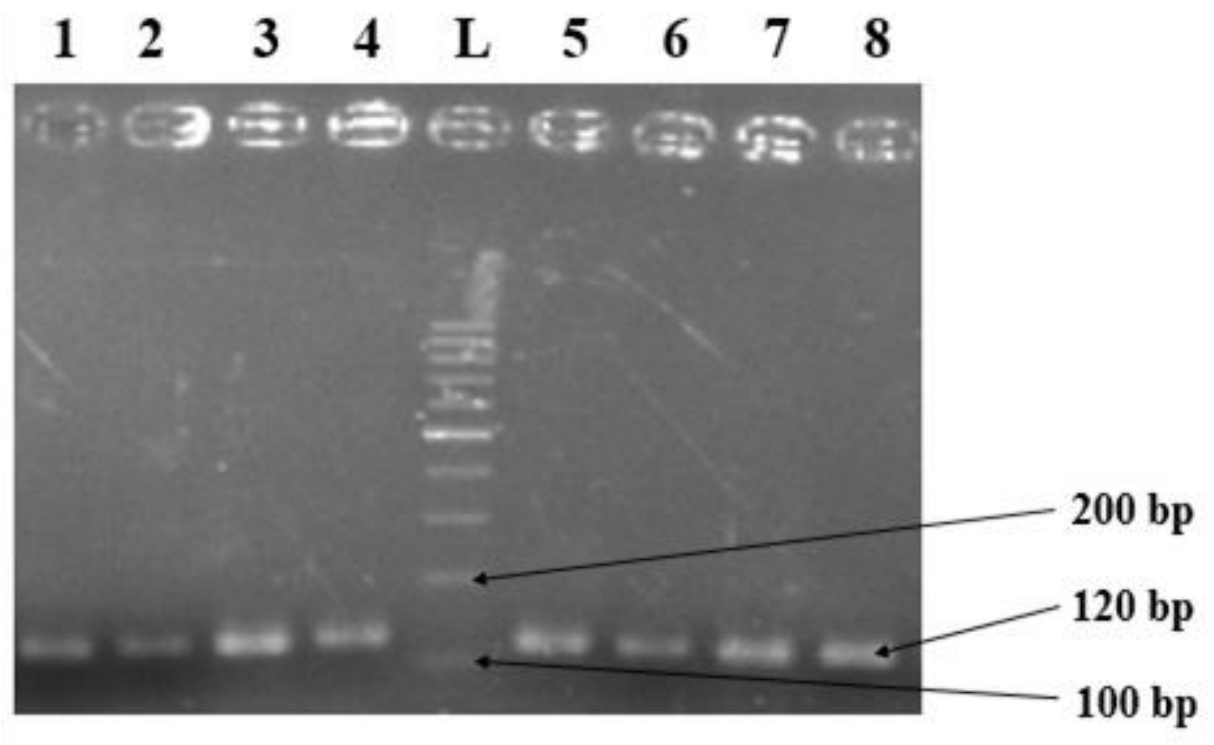

Figure 3.2: PCR product multiplied from ESR primers

(L: GeneRulerTM 100bp; Track 1 - 8: PCR product of ESR gene segment of F1 sow (ð̂wild boar $\mathrm{x}$ +VCNMS15)

The PCR results of the ESR gene segment are shown in Figure 3.2, showing that PCR is a single, bright, 120bp band as expected, eligible for the next steps.

3.2. Results of determining the correlation of genetic polymorphism of ESR gene with

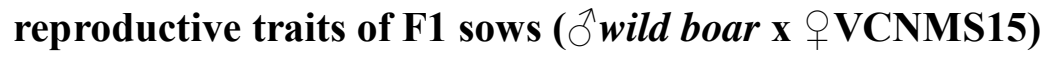

3.2.1. Results of ESR gene segment polymorphism analysis by enzyme PluII 
ESR gene polymorphism analysis was based on the cutting ability of the restriction enzyme PluII on PCR 120 bp. The product cut electrophoresis on 3.5\% agarose gel in 40 minutes. Results of ESR gene polymorphism analysis was shown in Figure 3.3.

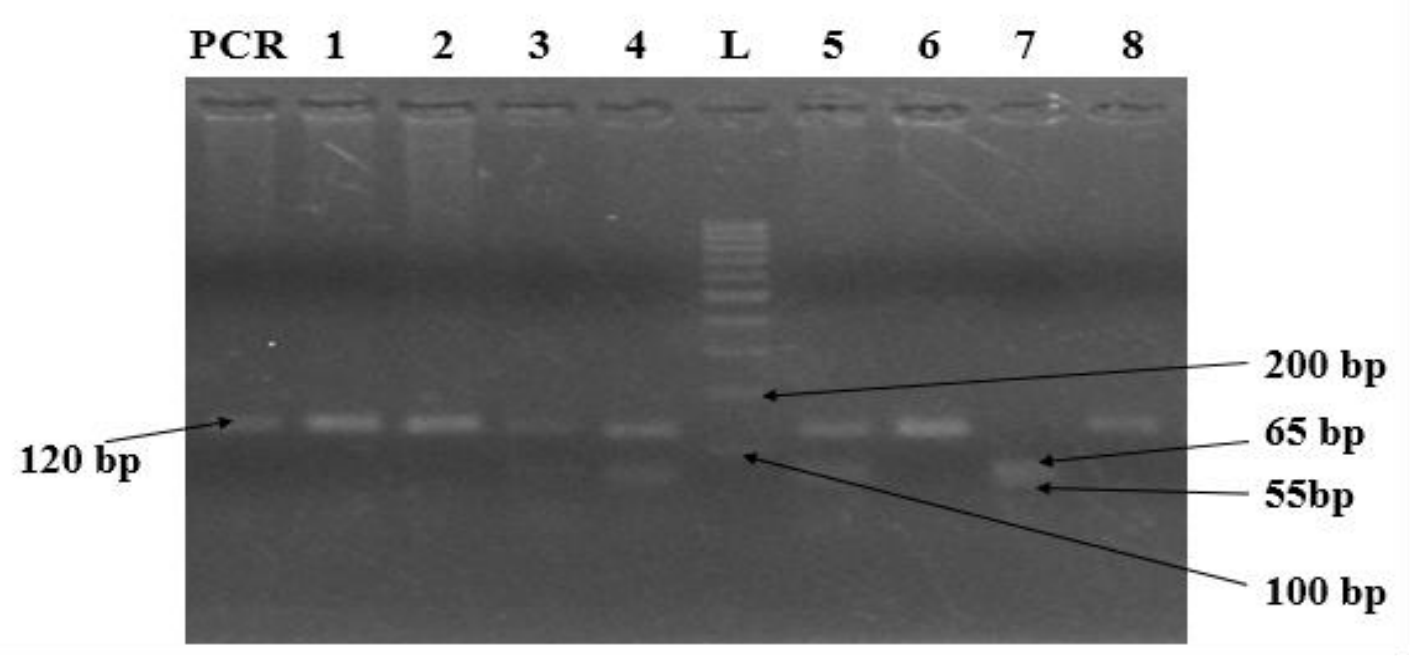

Figure 3.3: Results of ESR gene segment polymorphism analysis by PluII enzyme

(L: GeneRulerTM 100 bp; PCR: product PCR gene ESR; Genotype AA: 1,2,6,8 (120 bp); Genotype AB: 3,4,5 (120 bp, 65 bp, 55 bp) Genotype BB: 7 (65 bp, 55bp))

The picture above shows that the results of cutting the PCR product of ESR gene with PluII enzyme electrophoresis on the $3.5 \%$ gel for the bar band had been clearly separated. ESR gene segment after cleavage into DNA fragments of different sizes in which wells 1 and 6 were for genotype $\mathrm{AB}$; wells 2,4,5 for genotype AA; well 3 for the BB genotype. Genotypes of the ESR

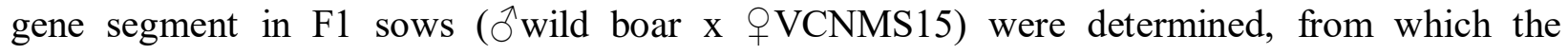
genotypes rate and allele frequency were also calculated based on the total number of individuals carrying that genotype. The results were shown in Table 3.2 and Figure 3.4 as follows:

Table 3.2. ESR genotype rate of F1 sows ( $\circlearrowleft$ wild boar $x$ VCNMS15)

\begin{tabular}{|c|c|c|c|c|c|c|}
\hline \multirow{2}{*}{$\begin{array}{c}\text { Number of } \\
\text { individuals } \\
\text { (n) }\end{array}$} & \multicolumn{2}{|c|}{ Genotype AA } & \multicolumn{2}{c|}{ Genotype AB } & \multicolumn{2}{c|}{ Genotype BB } \\
\cline { 2 - 7 } & $\begin{array}{c}\text { Number of } \\
\text { individuals }\end{array}$ & Ratio \% & $\begin{array}{c}\text { Number of } \\
\text { individuals }\end{array}$ & Ratio \% & $\begin{array}{c}\text { Number of } \\
\text { individuals }\end{array}$ & $\begin{array}{c}\text { Ratio } \\
\%\end{array}$ \\
\hline 20 & 8 & $40,00 \%$ & 11 & $55,00 \%$ & 1 & $5,00 \%$ \\
\hline
\end{tabular}


International Journal of Agriculture and Environmental Research

ISSN: 2455-6939

Volume: 07, Issue: 02 "March-April 2021"

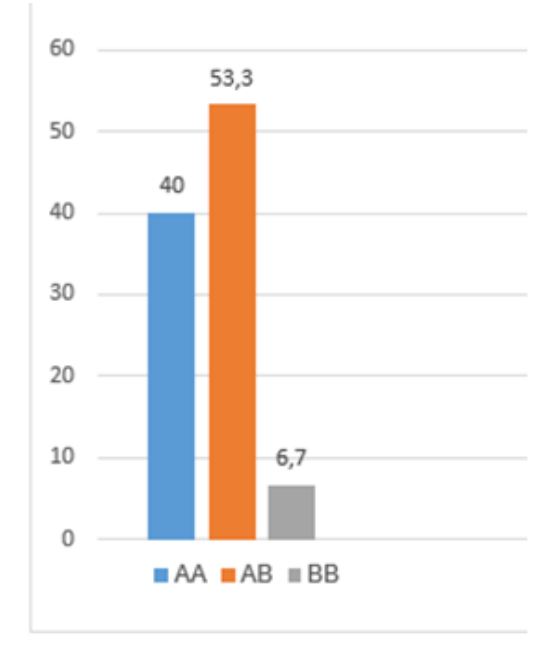

A) Percentage of genotypes ESR

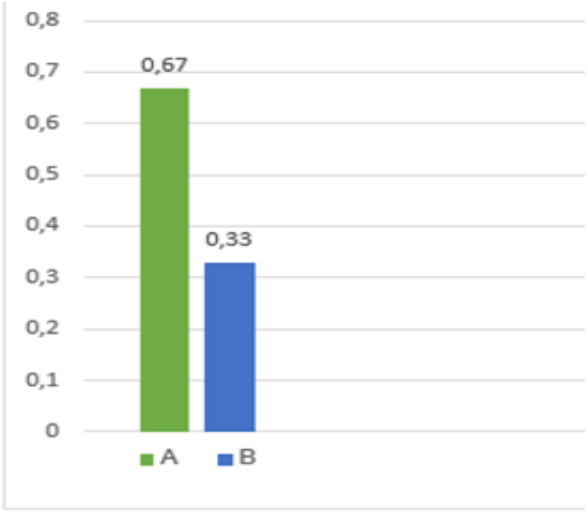

(B) Allele frequency of the ESR gene

Figure 3.4. Rate of genotype and frequency of the ESR allele in the studied pig population

The results in Table 3.2 and Figure 3.4 show that, when using PluII enzyme, analysis of ESR gene segment polymorphism in 20 pigs had the appearance of different genotypes. The F1

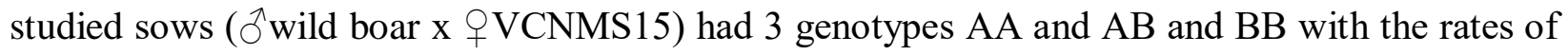
$40 \%, 55 \%$ and $5 \%$, respectively. In which, genotype $\mathrm{AB}$ was more dominant than genotypes AA and $\mathrm{BB}$. The difference in the $\mathrm{A}$ and $\mathrm{B}$ allele frequencies of the studied samples was clearly shown in Figure 3.4 B, where the A allele frequency of 0.67 accounted for a higher proportion than the $\mathrm{B}$ allele frequency of 0.33 .

By PCR technique Nguyen Van Cuong et al (2003) [1]; Nguyen Thi Dieu Thuy et al (2003; 2004) [3; 4] also identified genotypes related to number of offspring / parity through FSH gene analysis. Research by Rothschild et al (1996) [8]; Baskin et al. (1997) [5] showed that the B allele was closely related to the number of offspring born per litter. According to research by Suwanasopee et al (2010) [11], the genotype frequencies of ESR were 0.6965 respectively; 0.2601 and 0.0434 for genotypes $\mathrm{AA}, \mathrm{AB}$ and $\mathrm{BB}$, genotype $\mathrm{AA}$ had the highest frequency followed by $\mathrm{AB}$ and $\mathrm{BB}$.

R. Omelka et al. (2008) [9] studied on 155 heads of the Large White breed (LW), 134 heads of the White Meaty breed (WM) and 132 heads of the Landrace breed (L). The results obtained in the LW pig breed, the AA genotype frequency was 42.58; $\mathrm{AB}$ was 48.39 and $\mathrm{BB}$ was 9.03 . In the WM breed, the genotype frequency AA was 52.99; $\mathrm{AB}$ was 44.78 and $\mathrm{BB}$ was 2.23 . In the $\mathrm{L}$ 
International Journal of Agriculture and Environmental Research

ISSN: 2455-6939

Volume: 07, Issue: 02 "March-April 2021"

pig breed, genotype frequency AA was 84.09; $\mathrm{AB}$ was 15.91 and $\mathrm{BB}$ was 0 . The results on this LW pig breed were almost similar to the results obtained by the research topic.

\subsubsection{Results of research on effects of ESR gene polymorphism on the reproduction of F1 sows ( $\overbrace{}^{\lambda}$ Wild boar $\mathbf{x}+$ VCNMS15)}

Table 3.3: Some indicators of reproductive performance

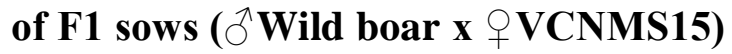

\begin{tabular}{|c|l|l|c|c|}
\hline No & \multicolumn{1}{|c|}{ Targets } & \multicolumn{1}{c|}{ Unit } & $\bar{X} \pm \mathrm{m} \bar{x}$ & Cv \% \\
\hline 1 & Number of piglets born & head / litter & $8,07 \pm 0,34$ & 18,58 \\
\hline 2 & $\begin{array}{l}\text { Number of piglets alive after } \\
24 \text { hours }\end{array}$ & head / litter & $7,88 \pm 0,30$ & 17,38 \\
\hline 3 & Newborn weight & $\mathrm{Kg} /$ head & $0,88 \pm 0,03$ & 14,86 \\
\hline 4 & Total litter weight & $\mathrm{Kg} /$ litter & $7,10 \pm 0,20$ & 12,28 \\
\hline 5 & Number of piglets weaned & $\mathrm{head} /$ litter & $7,28 \pm 0,28$ & 16,75 \\
\hline 6 & The weight of piglets weaned & $\mathrm{Kg} /$ head & $4,40 \pm 0,10$ & 14,43 \\
\hline 7 & Total weaning weight & $\mathrm{Kg} /$ head & $32,03 \pm 0,60$ & 11,80 \\
\hline
\end{tabular}

The results in Table 3.3 show that the reproductive productivity of $20 \mathrm{~F} 1$ sow pigs ( $₫$ Wild boar $\mathrm{x}$ +VCNMS15) raised in a farmer household in Phu Luong district, Thai Nguyen province had an average number of offspring of 8.07 . , with an average birth weight of $0.88 \mathrm{~kg} / \mathrm{head}$, weight of the whole nest reached $7.10 \mathrm{~kg} /$ litter. The average number of animals alive after 24 hours was 7.88 / litter; The number of piglets weaned was 7.28 heads / litter with an average weight of $4.06 \mathrm{~kg} / \mathrm{head}$ and total weaning weight was $29.56 \mathrm{~kg} / \mathrm{head}$. These are synthetic indicators, reflecting reproductive performance of sows, Legault C. (1985) [7].

\subsubsection{The sow's reproductive performance corresponds to the genotypes of the ESR gene}

After analyzing the genotypes and statistics of the number of sows corresponding to each genotype of ESR in the survey, the results showed that $20 \mathrm{~F} 1$ sows ( $\overbrace{}^{A}$ Rung $\mathrm{x}$ q VCNMS15) had 8 sows with genotype $\mathrm{AA}, 11$ a sow with genotype $\mathrm{AB}$, and a sow with genotype $\mathrm{BB}$, were shown in table 3.4 . 
International Journal of Agriculture and Environmental Research

ISSN: 2455-6939

Volume: 07, Issue: 02 "March-April 2021"

Table 3.4: Reproductive performance corresponding to genotypes in F1 sows ( 3 Wild boar $x$ ㄷNMS15)

\begin{tabular}{|c|c|c|c|c|c|c|c|}
\hline Target & Genotype & $\mathbf{n}$ & $\begin{array}{l}\text { average } \\
\quad \bar{X}\end{array}$ & $\begin{array}{c}\text { Standard } \\
\text { deviation } \\
\text { S }\end{array}$ & $\begin{array}{c}\text { Standard } \\
\text { error } \\
\mathrm{m} \bar{x}\end{array}$ & $\begin{array}{c}\mathbf{F} \\
\text { value }\end{array}$ & $\begin{array}{c}P \\
\text { value }\end{array}$ \\
\hline \multirow{3}{*}{$\begin{array}{l}\text { Number of piglets } \\
\text { born(head / litter) }\end{array}$} & $\mathrm{AA}$ & 8 & 6,50 & 1,20 & 0,42 & \multirow{3}{*}{6,20} & \multirow{3}{*}{$\mathrm{P}<0,05$} \\
\hline & $\mathrm{AB}$ & 11 & 8,40 & 1,40 & 0,42 & & \\
\hline & $\mathrm{BB}$ & 1 & 6,0 & 0 & 0 & & \\
\hline \multirow{3}{*}{$\begin{array}{c}\text { Number of piglets } \\
\text { alive after } 24 \\
\text { hours (head / } \\
\text { litter) }\end{array}$} & AA & 8 & 6,40 & 1,37 & 0,56 & \multirow{3}{*}{5,80} & \multirow{3}{*}{$\mathrm{P}<0,05$} \\
\hline & $\mathrm{AB}$ & 11 & 8,20 & 1,43 & 0,50 & & \\
\hline & $\mathrm{BB}$ & 1 & 6,00 & 0 & 0 & & \\
\hline \multirow{3}{*}{$\begin{array}{c}\text { Newborn weight } \\
(\mathrm{kg} / \mathrm{head})\end{array}$} & AA & 8 & 0,84 & 0,09 & 0,04 & \multirow{3}{*}{5,11} & \multirow{3}{*}{$\mathrm{P}<0,05$} \\
\hline & $\mathrm{AB}$ & 11 & 1,00 & 0,14 & 0,05 & & \\
\hline & $\mathrm{BB}$ & 1 & 0,75 & 0,12 & 0,04 & & \\
\hline \multirow{3}{*}{$\begin{array}{l}\text { Total litter } \\
\text { weight(kg/litter) }\end{array}$} & AA & 8 & 6,00 & 0,60 & 0,20 & \multirow{3}{*}{5,78} & \multirow{3}{*}{$\mathrm{P}<0,05$} \\
\hline & $\mathrm{AB}$ & 11 & 8,20 & 1,22 & 0,43 & & \\
\hline & BB & 1 & 5,50 & 0 & 0 & & \\
\hline
\end{tabular}

The analysis results on $20 \mathrm{~F} 1$ sows ( ${ }^{A}$ Forest $\mathrm{x}$ + $\mathrm{VCNMS15}$ ) showed that the criteria for the number of piglets born and the number of piglets alive after 24 hoursin genotype $\mathrm{AB}$ were higher than genotypes AA and BB. respectively: 8.40 - 8.20 head/litter and 6.50 - 6.40 head/litter; 6.00 6.00 each. Similar to the target of birth weight in sows with genotype AB higher than sows with genotypes AA and BB, respectively: $1.00 \mathrm{~kg} /$ head and 0.840 to $0.75 \mathrm{~kg} / \mathrm{head}$ with $(\mathrm{P}<0.05)$.

Thus, the avarage values of some reproductive indicators of F1 wild sows ( $う$ wild boar $\mathrm{x}$ OVCNMS15) corresponding to the genotypes had a statistically significant difference with (P $<0.05)$. From there, it showed that there was an influence by genotype factors on reproductive performance of sows.

There were many studies related to genetic polymorphism of ESR genes such as Rothschild et al. (1996) [8] analysis of ESR gene polymorphism of pigs revealed that there was a characteristic 
International Journal of Agriculture and Environmental Research

ISSN: 2455-6939

Volume: 07, Issue: 02 "March-April 2021"

allele associated with the number of newborn babies. Short et al. (1997) [10] investigated the effect of ESR gene loci on reproductive and production traits of commercial pig lines revealed a correlation of total live offspring with beneficial alleles of the ESR gene. Goliasova and Woft (2004) [12] analysis of the ESR gene polymorphism of pigs showed that the ESR gene locut significantly influenced the number of newborns at parity 1 and litter. Analysing of genotypes ESR showed that pigs with genotype BB had a superior number of live offspring compared to genotypes $\mathrm{AA}$ and $\mathrm{AB}$ in the first and subsequent parities.

Improving genetics by genetic technology in breeding livestock has been applied by many countries around the world to increase the productivity and quality of livestock. Through the study of ESR gene polymorphism of F1 sows ( ${ }^{\lambda}$ Wild Boar $\mathrm{x}$ ๆ VCNMS15), it could be initially confirmed that there was a correlation between the ESR gene polymorphism to the reproductive performance of $\mathrm{F} 1$ sows ( $0^{\lambda}$ Wild Boar $\mathrm{x}$ + VCNMS15) ). However, the sample was not large enough to be able to draw conclusions about exactly which genotype had the greatest effect on reproductive performance. The study also paved the way to conduct further studies on the effect of ESR genotype polymorphism on the fertility of F1 hybrid forest sows ( $ð$ Wild Boar x $९$ VCNMS15).

\section{CONCLUSION}

The results of analysis and investigation of the effect of the relationship between the ESR gene polymorphism with the reproductive traits of F1 hybrid wild boar ( ${ }^{\Uparrow}$ Wild boar x 9 VCNMS15) showed that:

Successfully analyzed ESR gene polymorphism from 20 individuals of F1 sow ( $\overbrace{}^{\lambda}$ Wild boar $\mathrm{x}$ + VCNMS15) and identified 3 genotypes AA; AB; BB. The results obtained the difference in genotype specific as follows: 8 individuals with genotype AA accounted for 40\%, 11 individuals with genotype $\mathrm{AB}$ accounted for $55.00 \%$ and 1 individual with genotype $\mathrm{BB}$ accounted for 5 , $00 \%$. The difference in the A and B allele frequencies of the studied samples was clearly shown, the A allele frequency of 0.67 accounted for a higher percentage than the B allele frequency of 0.33 .

Initially, the correlation between ESR genotype polymorphism was determined for the reproductive traits of $\mathrm{F} 1$ pigs ( $\lesssim$ Wild boarx + VCNMS15). Pigs carrying genotype AB in ESR gene showed higher reproductive performance than genotypes $\mathrm{AA}$ and $\mathrm{BB}$ with $(\mathrm{P}<0.05)$. 
International Journal of Agriculture and Environmental Research

ISSN: 2455-6939

Volume: 07, Issue: 02 "March-April 2021"

\section{REFERENCES}

1. Nguyen Van Cuong, Nguyen Thi Dieu Thuy, Dau Hung Anh, Nguyen Kim Do (2003), Research on genetic polymorphism of some Vietnamese pig breeds, Basic research issues in life sciences, p.852 -857.

2. Khuat Huu Thanh (2012), Institute of Molecular Genetics and Gene Engineering, Science and Technology Publishing House, Hanoi.

3. Nguyen Thi Dieu Thuy, Nguyen Thu Thuy, Nguyen Van Cuong, A.W.Kuss.H. Geldermann (2004). Ovarian stimulating hormone gene polymorphism (FSH) in some breeds of pigs in Vietnam. Applied Genetics, (1), pp.14-18

4. Nguyen Thi Dieu Thuy, Nguyen Van Cuong, Nguyen Thu Thuy, Nguyen Dang Vang, Pham Anh Tuan (2003). Developing genetic indicators for traits of economic significance for animal breeding. National Biotechnology Conference Scientific Report 2003, pp.1238-1243.

5. Baskin L.C, D.Pomp (1997), Rapid communication: restriction fragment length polymorphism in amplification products of the porcine growth hormone-releasing hormone gene, J Anim Sci 75(8): 2285.

6. Drogemuller C., H. Hamanm and O. Distl (2001), Cadidate gene markers for litter size in different German pigs line, J. Anim. Sci.

7. Legault C. (1985). Selection for breeds, straits and individual pigs for prolificacy. Journal of reproduction and fertility 33 (suppl): 156 - 166.

8. Rothschild Max, Carol Jacobson and David Vaske (1996),The estrogen receptor locus is associated with a major gene influencing litter size in pigs, Roc, Natl. acad. Sci, USA .

9. OmelkaR.M. Martiniaková1, D. Peškovičová2 and M. Bauerová (2008), Associations between AluI Polymorphism in the Prolactin Receptor Gene and Reproductive Traits of Slovak Large White, White Meaty and Landrace Pigs, Asian-Aust. J. Anim. Sci. , Vols. No. $4: 484-488$.

10. Short T. H., Rothschild M. F., Southwood O.I., MacLaren D. G., DeVries A. van der Steen H., Eckardt G. R., Tuggler C. K., Helm J., Vaske D. A., Mileham A. J. and Plastow G. S. (1997), The effect of the estrogen receptor locus on reproduction and production traits in four commerial lines of pigs, Journal of Animal Science 75:3138-3142. 
International Journal of Agriculture and Environmental Research

ISSN: 2455-6939

Volume: 07, Issue: 02 "March-April 2021"

11. Suwanasopee T., Thengpimol, P., Koonawoo- trittriron, S. and Chanthapanya (2010), Effect of Estrogen Receptor (ESR) genotypes on litter size and weaning to estrus interval in a Thai commercial swine population, In: Proc 14th AAAP Animal Science Congress.

12. Goliasova E.,J. Wolf (2004), Impact of the ESR gene on litter size and production traits in Czech Large white pigs. Anim. Genet 35: 293-297. 